\title{
Heat-shock protein 60 homologue of Helicobacter pylori is associated with adhesion of $H$. pylori to human gastric epithelial cells
}

\author{
H. YAMAGUCHI, T. OSAKI*, N. KURIHARA $\dagger, H$. TAGUCHI, T. HANAWA, T. YAMAMOTO \\ and S. KAMIYA \\ Department of Microbiology and * Division of Flowcytometry, Kyorin University School of Medicine, Mitaka, \\ Tokyo 181 and †Department of Surgery, Keio University School of Medicine, Shinanomachi, Shinjuku, Tokyo \\ 160, Japan
}

\begin{abstract}
A previous study reported a relationship between the expression of heat-shock protein 60 (HSP60) by Helicobacter pylori and its adhesion to human gastric carcinoma (MKN45) cells. To examine whether the HSP60 homologue of $\boldsymbol{H}$. pylori is associated with the adhesion of $\boldsymbol{H}$. pylori to human gastric epithelial cells, an inhibition assay of adhesion of $H$. pylori to MKN45 cells was performed by flow cytometric analysis with monoclonal antibody (MAb) designated as H20 recognising HSP60 of $H$. pylori. The rate of adhesion of $H$. pylori pretreated with MAbH20 to MKN45 cells was lower than that of untreated $H$. pylori. Primary human gastric epithelial cells from a patient with gastric cancer were also prepared for comparison in the inhibition assay with MAbH20. $H$. pylori adhered to the primary human gastric epithelial cells, and this adhesion was significantly inhibited by MAbH20. These results suggest that the $H$. pylori HSP60 homologue recognised by MAbH20 might be associated with the adhesion of $H$. pylori to primary human gastric epithelial cells as well as to cultured gastric cancer cells.
\end{abstract}

\section{Introduction}

Helicobacter pylori is associated with chronic gastritis, gastroduodenal ulcer and gastric adenocarcinoma [13]. Although virulence factors such as flagella [4, 5], adhesin [6], urease $[7,8]$, vacuolating toxin $[9,10]$ and the toxin that inhibits secretion of gastric acid in vitro $[11,12]$ have been identified, the relationship between these $H$. pylori antigens and the mechanism by which H. pylori persists in the stomach is not clear.

A study of bacteria-epithelial cell adhesion, the first step in $H$. pylori infection, is important for any understanding of the mechanism of induction of tissue inflammation in the stomach by $H$. pylori to emerge. Several ligand-receptor interactions between $H$. pylori and gastric epithelial cells have been reported: $\mathrm{N}$ acetylneuraminyllactose-binding fibrillar haemagglutinin [13], haemagglutination activities with strain specificity $[13,14]$, binding to GM3 ganglioside and sulphatides $[15,16]$, and a laminin-binding protein $[14,17]$ have been demonstrated. These indicate that

Received 19 Nov. 1996; revised version accepted 17 Feb. 1997.

Corresponding author: Dr H. Yamaguchi. the adhesion of $H$. pylori to human gastric epithelial cells might be multifactorial.

A recent study demonstrated that there is a correlation between the adhesion of $H$. pylori to human gastric carcinoma cells and the expression of heat-shock protein 60 (HSP60) on the cell surface [18]. Huesca et al. [19] reported that HSP60 of H. pylori localised on the bacterial surface, which mediates sulphatide recognition, might be related to the adhesion of $H$. pylori to gastric epithelial cells. HSP60, conserved not only in prokaryotic cells but also in eukaryotic cells, is thought to facilitate folding, unfolding and translocation of polypeptides as chaperonins [20-25]. Accordingly, the interaction between HSP60 of $H$. pylori and the adherence characteristics of $H$. pylori is important for an understanding of the mechanism of persistent infection with $H$. pylori.

In the present study, in order to clarify whether $H$. pylori HSP60 is associated with adhesion to human gastric epithelial cells, an inhibition assay of adhesion to human gastric carcinoma cells (MKN45) was performed. These experiments were repeated with primary human gastric epithelial cells from a patient with gastric cancer. 


\section{Materials and methods}

\section{Bacterial strains and culture conditions}

H. pylori strain TK1029 used in this study was isolated from gastric biopsy material of a patient as described previously [26]. The bacteria were cultured on Brain Heart Infusion (BHI) Agar (Difco) with defibrinated horse blood $5 \%$ in an atmosphere of $\mathrm{O}_{2} 5 \%, \mathrm{CO}_{2} 10 \%$, $\mathrm{N}_{2} 85 \%$ for 4 days at $37^{\circ} \mathrm{C}$. Cells of $H$. pylori TK 1029 were centrifuged at $3000 \mathrm{~g}$ for $15 \mathrm{~min}$ and resuspended in Hanks's Balanced Salts Solution (Gibco) containing gelatin $0.1 \%$ (Sigma) (HGS) for flow cytometric analysis.

\section{Cell line}

Human gastric carcinoma (MKN45) cells were obtained from the Japanese Cancer Research Resources Bank (JCRB). They were grown at $37^{\circ} \mathrm{C}$ in RPMI 1640 (Gibco) containing fetal calf serum (FCS; Wako Pure Chemical Ltd, Osaka, Japan) $10 \%$ in an atmosphere of air with $\mathrm{CO}_{2} 5 \%$. The cells were resuspended in HGS for flow cytometric analysis.

\section{Preparation of primary human gastric epithelial cells}

For the preparation of primary human gastric epithelial cells, a specimen of gastric mucosa $(c .5 \mathrm{~cm}$ square, $50 \mathrm{~g}$ ) was obtained from a patient undergoing surgery for gastric carcinoma. The specimen was negative in tests for both rapid urease and isolation of $H$. pylori. The specimen was stored at $4^{\circ} \mathrm{C}$ in RPMI 1640 medium containing FCS $10 \%$ (RF-10). The specimen was then shaken for $60 \mathrm{~min}$ at $37^{\circ} \mathrm{C}$ with $50 \mathrm{ml}$ of pronase solution $(10 \mathrm{mg} / \mathrm{ml}$; Pronase MS, Kaken Seiyaku Co. Ltd, Tokyo, Japan) which is a gastric mucinolytic agent. The cell suspension was centrifuged at $1200 \mathrm{rpm}$ for $10 \mathrm{~min}$, and the cell pellet was suspended in RF-10 with Percoll (Sigma) 10\% followed by centrifugation at $1800 \mathrm{rpm}$ for $18 \mathrm{~min}$. Subsequently, the cell pellet was suspended again in RF-10 with Percoll $44 \%$ and the prepared suspension was put on to RF-10 with Percoll $70 \%$. After centrifugation at $1800 \mathrm{rpm}$ for $18 \mathrm{~min}$, the whole cells on the Percoll $70 \%$ were recovered and washed twice with RF-10. The cells formed the preparation of primary human gastric epithelial cells.

\section{Preparation of monoclonal antibodies}

The monoclonal antibody (MAb) was prepared by the methods described previously [27]. BALB/c mice were immunised intraperitoneally (i.p.) with partially purified $60-\mathrm{kDa}$ antigen derived from H. pylori TK1029, which had been extracted from the separating gel of SDS-PAGE. These inoculations in Freund's complete adjuvant (Difco) were made at intervals of 10 days. Ten days after the last injection, the mice were given an intravenous injection of the partially purified antigen and 3 days later the spleens were removed for fusion of spleen cells and mouse myeloma cells (P3-X63-Ag8$\mathrm{U1}$ ). The hybridoma producing $\mathrm{MAb}$ which reacted with the partially purified antigen, purified HSP60 from Yersinia enterocolitica [28] and the sonicated MKN45 cells were collected. The hybridoma with apparent specific antibody production was cloned by limiting dilution and designated as $\mathrm{MAbH} 20$ (class: IgM). The hybridoma cells $\left(10^{6}\right.$ cells) were inoculated i.p. into a BALB/c mouse pre-treated intraperitoneally with $0.5 \mathrm{ml}$ of pristane (Wako Pure Chemical) 4 days before the inoculation of the cells. About 2 weeks later, ascites fluid was obtained from the mouse. The immunoglobulins in the ascitic fluid were purified with an Immunoglobulin-Easy-Separation kit (Pharmacia Biotech. Co., Tokyo, Japan). The purified MAbs were used for flow cytometric analysis.

\section{Microsequencing of protein}

To examine whether the molecule of $H$. pylori recognised with MAbH20 was HSP60, microsequencing of the N-terminal amino acids of the protein was performed. The whole proteins of $H$. pylori TK1029 were separated by SDS-PAGE and transferred on to an Immobilon membrane (Millipore, Bedford, MA, USA). The band corresponding to the protein recognised by $\mathrm{MAbH} 20$ was excised from the membrane and sequenced on a protein sequencer (473A; Applied Biosystems, Foster City, CA, USA).

\section{Flow cytometric analysis}

The inhibition assay of $H$. pylori adhesion to MKN45 and primary human gastric epithelial cells was performed by the method described by Osaki et al. [29]. Lipophilic dye PKH-2 (Zynaxis Cell Sciences, Phoenixville, PA, USA) was used to label $H$. pylori as described by Taguchi et al. [30]. H. pylori labelled with $\mathrm{PKH}-2$ and MKN45 cells were pre-treated with $200 \mu \mathrm{g} / \mathrm{ml}, 40 \mu \mathrm{g} / \mathrm{ml}$ and $8 \mu \mathrm{g} / \mathrm{ml}$ of $\mathrm{MAbH} 20$. PKH2-labelled $H$. pylori with or without treatment with $\mathrm{MAbH} 20$ were incubated with either MKN45 cells or primary gastric epithelial cells at $37^{\circ} \mathrm{C}$ for $1 \mathrm{~h}$ in a 1.5 $\mathrm{ml}$ tube with gentle shaking. Non-adherent bacteria were removed by centrifugation with $9 \mathrm{ml}$ of sucrose $15 \%$ solution. After the cells were washed four times with HGS, they were resuspended in $300 \mu 1$ of HGS for flow cytometric adherence assay. A flow cytometer (FACSvantage Coulter Electronics, Hialeah, USA) was used for the measurement of fluorescence intensity. Fluorescence data were obtained in a logarithmic mode on a 1024 channel scale. The results were shown as peak fluorescence intensity and mean (SD) channel indicating the fluorescence frequency distribution histograms. 


\section{Results}

Preparation of primary human gastric epithelial cells

The profiles containing side and forward scatter of the prepared cells by flow cytometry are shown in Fig. 1. The group of large cells (arrow) was thought to comprise human gastric epithelial cells. In addition, cell morphology was also ascertained for these large cells (Fig. 2). The viability of these cells was determined with propidium iodide (Wako Pure Chemical), and was found to be $95 \%$. This group of cells was gated, and the gated cells were analysed in the inhibition assay of adhesion of $H$. pylori to primary human gastric epithelial cells.

Sequencing of N-terminal amino acids of the 60$k D a$ antigen of $H$. pylori recognised with $\mathrm{MAbH} 20$

The N-terminal amino acid sequence of the $H$. pylori $60-\mathrm{kDa}$ antigen recognised with $\mathrm{MAbH} 20$ was analysed. The sequence, ${ }^{* * * *} \underline{I K F S V Y \underline{A M K L L F E G V}}$ ( $^{*}$ denotes unsuccessful determination), of the first 19 amino acids was determined. Eleven amino acids (underlined) corresponded to the $\mathrm{N}$-terminal amino acids of $H$. pylori HSP60 previously reported by Macchia et al. [31].

\section{Inhibition of adhesion of $H$. pylori to human gastric carcinoma MKN45 cells by MAbH2O}

Fig. 3 shows the representative patterns of the inhibition of $H$. pylori adhesion to MKN45 cells by $\mathrm{MAbH} 20$, directed to $H$. pylori HSP60. In $H$. pylori pre-treated with $\mathrm{MAbH} 20$, the fluorescence intensity of the peaks that indicate the adhesion rate of $H$. pylori to MKN45 were significantly decreased (Fig. 3c). The decrease of the adhesion rate was dependent on the concentrations of MAbH20 used (8, 40 or $200 \mu \mathrm{g} / \mathrm{ml}$ ). Each adhesion rate, indicated as mean channel (SD) when treated with MAbH20, was 182.3 (86.8), 185.9 (51.3) and 42.2 (25.4) for the results in Fig. 3a, b and $\mathrm{c}$, respectively. There was a significant difference in adhesion when $H$. pylori was pre-treated with $\mathrm{MAb}$ and untreated organisms (Mann-Whitney $U$ test, $\mathrm{p}<0.0001$ ) (Table 1). However, there was no significant difference in the adhesion rates of $H$. pylori when MKN45 cells were pre-treated with MAbH20 $(8-40 \mu \mathrm{g} / \mathrm{ml})$, in comparison to non-pre-treated control. These results indicate that $H$. pylori HSP60 might mediate the adhesion of $H$. pylori to human gastric carcinoma MKN45 cells.

\section{Inhibition of adhesion to $H$. pylori to primary human gastric epithelial cells}

Human gastric epithelial cells from a patient with gastric cancer were prepared for use in the inhibition assay with MAbH20. As shown in Figs. 1 and 2, the prepared cells contained a large population of human gastric epithelial cells. The relative proportion of the population of gastric cells which were epithelial was $c$. $25 \%$. The mean channel number of the gastric epithelial cells adhered with $H$. pylori TK1029 was 188.1 (SD 51.3), and that of negative control of the epithelial cells without $H$. pylori was 3.1 (1.0) (Fig. 4). The results indicate that $H$. pylori TK1029 could adhere to the primary human gastric epithelial cells. When $H$. pylori was pre-treated with each concentration $(125-1000 \mu \mathrm{g} / \mathrm{ml})$ of $\mathrm{MAbH} 20$, the adhesion rates of $H$. pylori to the primary epithelial cells were

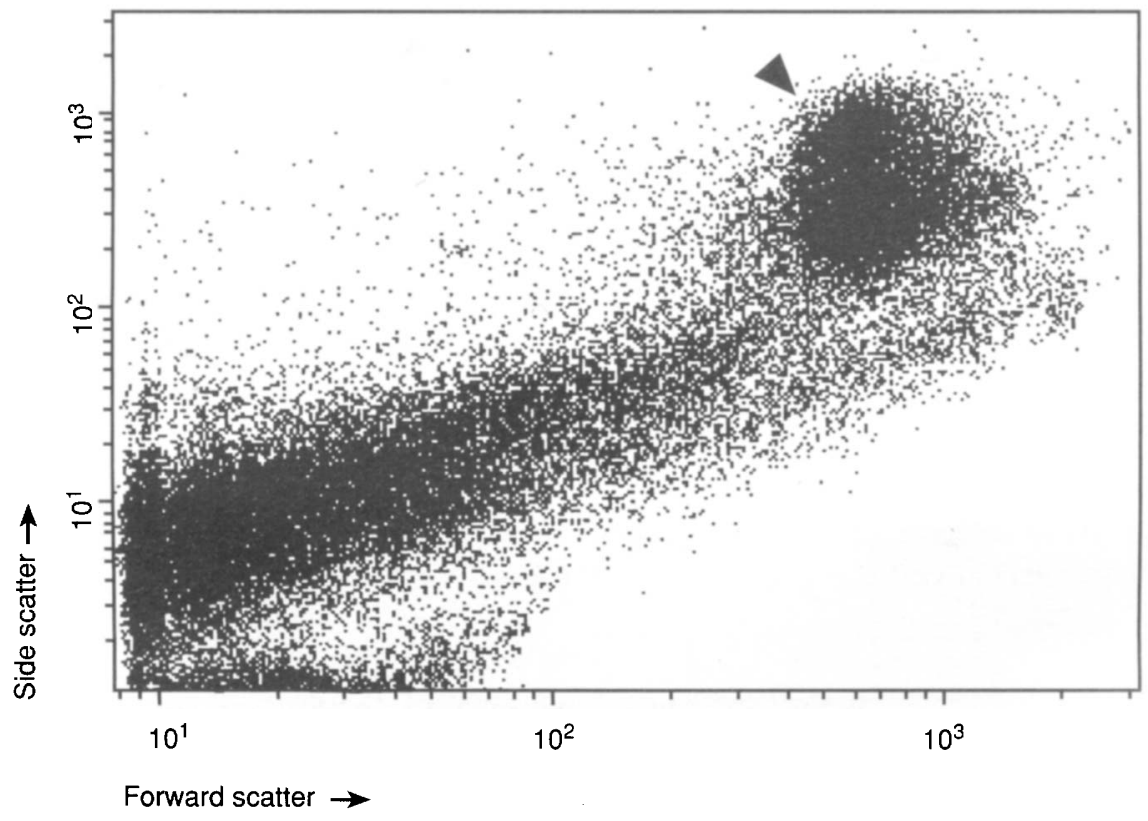

Fig. 1. Flow cytometry analysis of primary human gastric epithelial cells from gastric tissue of a patient with gastric cancer. Forward scatter ( $\mathrm{x}$ axis) indicates cell size and side scatter ( $\mathrm{y}$ axis) indicates molecular density in the cell. The cell group with greater size and density (arrow) is thought to comprise human gastric epithelial cells. 


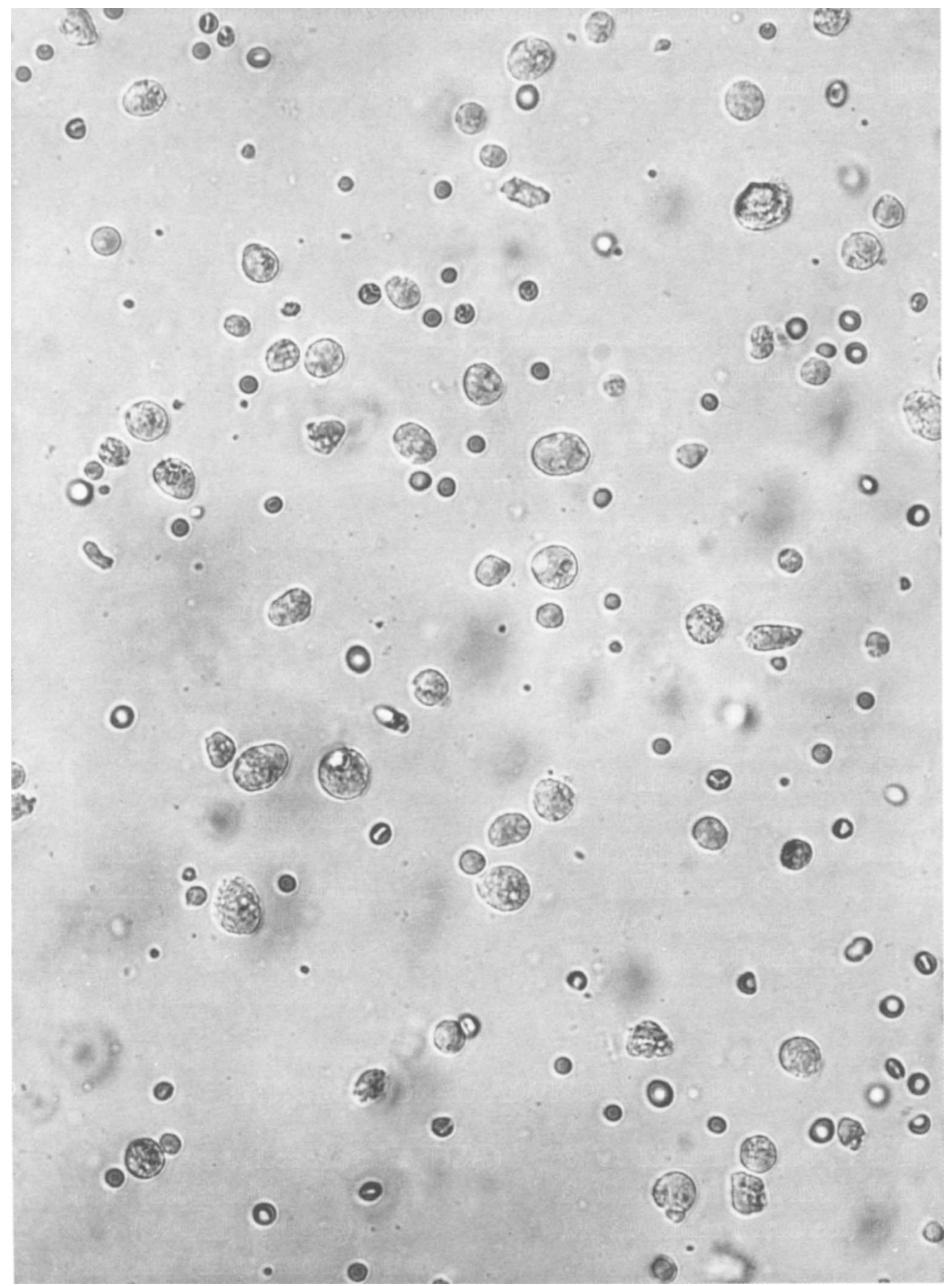

Fig. 2. Morphological features of the prepared human gastric cells $(\times 200)$.

significantly decreased compared with the positive control, depending on the concentration of the MAb (Fig. 4). These results suggest that $\mathrm{MAbH} 20$ directed to $H$. pylori HSP60 could inhibit the adhesion of $H$. pylori not only to cultured MKN45 cells but also to primary human gastric epithelial cells.

\section{Discussion}

A recent report showed that there is a significant correlation between the expression of $H$. pylori HSP60 on the cell surface and the adhesion of $H$. pylori to human gastric carcinoma MKN45 cells [18]. Phadnis et al. [32] have shown that $H$. pylori HSP60 exists on the cell surface and adheres to extracellular antigen. Huesca et al. [19] have also reported that $H$. pylori HSP60 localising on the bacterial surface, which mediates sulphatide recognition, might be related to the adhesion of $H$. pylori to gastric epithelial cells. These findings suggest that $H$. pylori HSP60 might be an adhesin and could be directly associated with the adhesion of $H$. pylori to gastric epithelial cells.

The present study established that $\mathrm{MAbH} 20$ is directed against $H$. pylori HSP60 and also demonstrated that the MAb inhibits the adhesion of H. pylori to MKN45 cells. The results indicate that $H$. pylori HSP60 could 
a

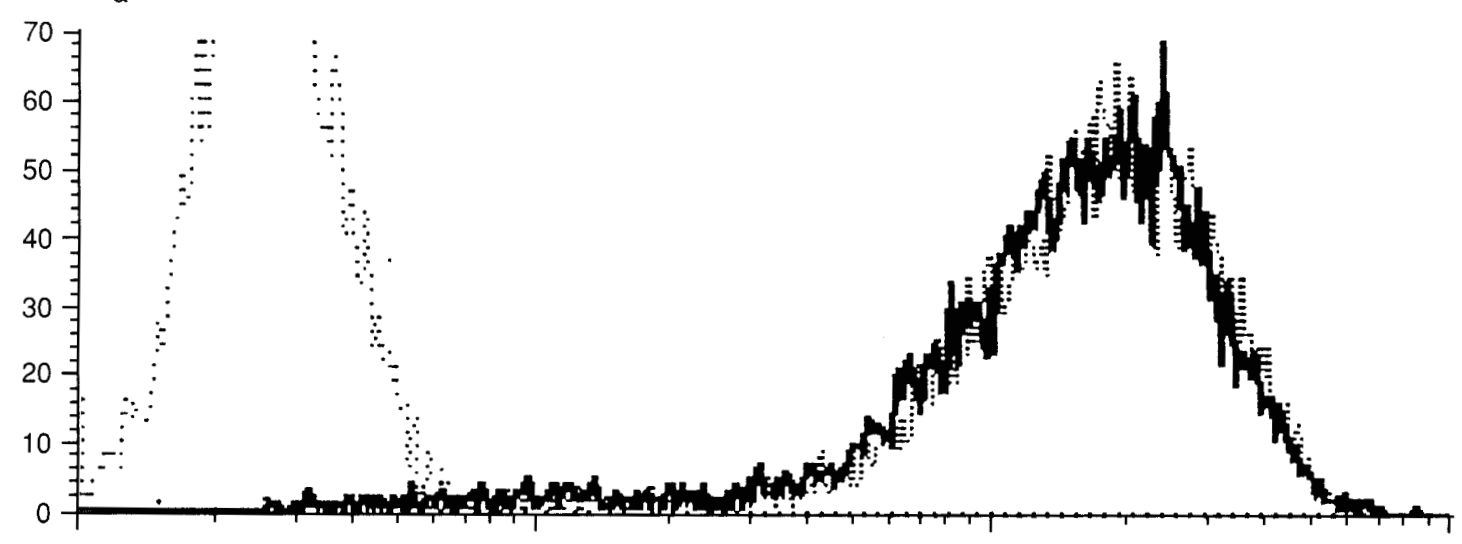

b
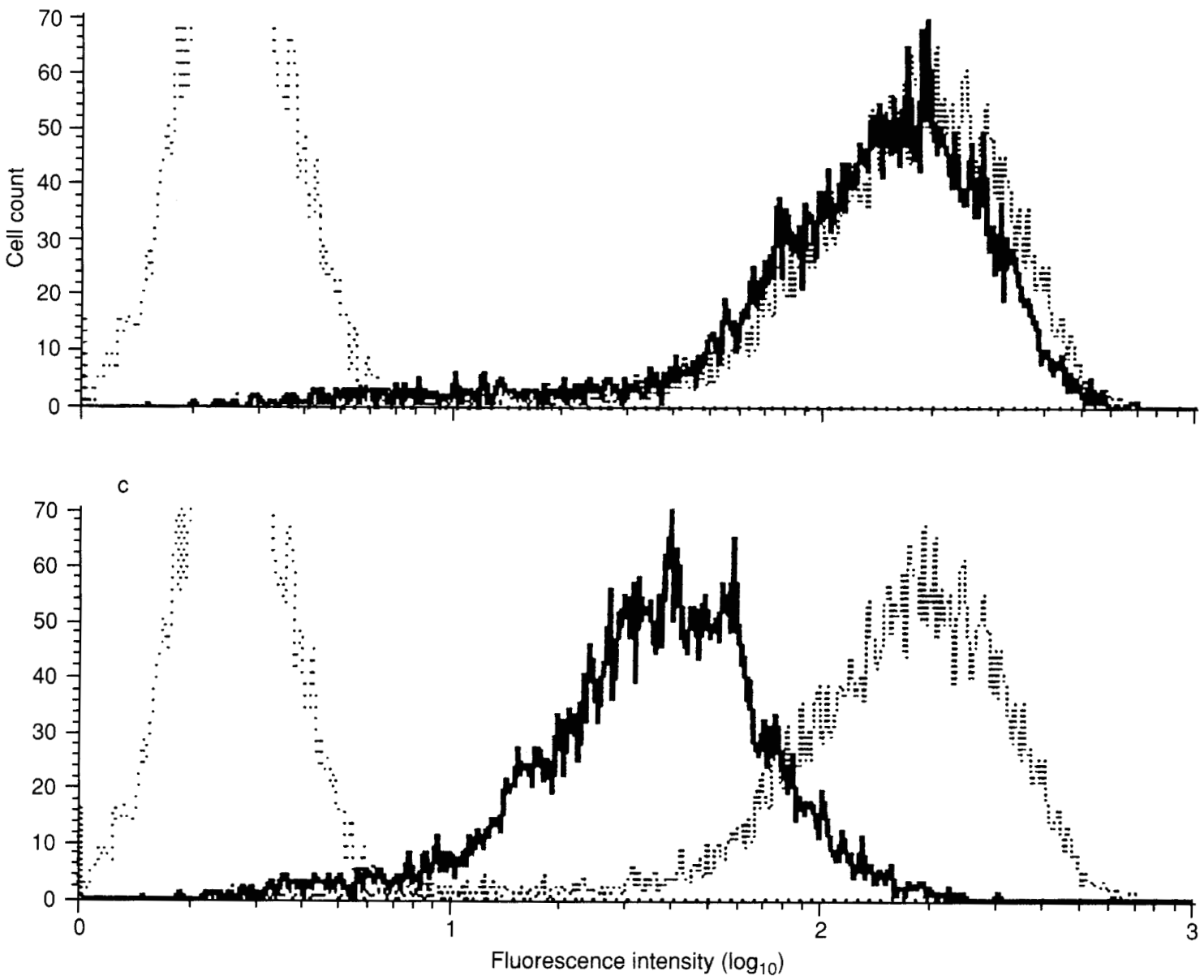

Fig. 3. Representative patterns in flow cytometric analysis of adherence inhibition of $H$. pylori to MKN45 cells by MAbH20. a, MKN45 cells were pre-treated with MAbH20 at $4^{\circ} \mathrm{C}$ for $1 \mathrm{~h}$, and incubated with H. pylori; b, H. pylori was incubated with MKN45 cells at $4^{\circ} \mathrm{C}$ for $1 \mathrm{~h}$ in the presence of MAbH20; c, H pylori was pre-treated with $\mathrm{MAbH} 20$ at $4^{\circ} \mathrm{C}$ for $1 \mathrm{~h}$ and incubated with MKN45 cells. MAb H20 diluted to $8 \mu \mathrm{g} / \mathrm{ml}$ was used; - , shows the results of the inhibition assay with the $\mathrm{MAb} ; \cdots$, shows the negative control, indicating the fluorescence intensity of MKN45 cells only; $\cdots$, shows the positive control, indicating the fluorescence intensity of MKN45 to which $H$. pylori has adhered in the absence of the MAb.

be related to the adhesion of $H$. pylori to human gastric carcinoma MKN45 cells.

As MKN45 cells are not thought to be natural cells derived from human gastric tissue, primary human gastric epithelial cells were prepared from a patient with gastric cancer. As shown in Fig. 4, H. pylori adhered to the primary human gastric epithelial cells. Osaki et al. [29] previously reported that the adhesion of $H$. pylori to three human gastric carcinoma cell lines (MKN45, KATOIII and MKN28) differed, showing that the cell line MKN45 was the most 
Table 1. Inhibitory effect of MAbH20 on adhesion of $H$. pylori to MKN45 cells

\begin{tabular}{lccc}
\hline & \multicolumn{3}{c}{ Mean (SD) fluorescence intensity* } \\
\cline { 2 - 4 } \begin{tabular}{l} 
Concentration $\begin{array}{l}\text { of MAbH20 } \\
(\mu \mathrm{g} / \mathrm{ml})\end{array}$ \\
\cline { 2 - 4 }
\end{tabular} & $\begin{array}{c}\text { Pre-treatment } \\
\text { of H. pylori }\end{array}$ & $\begin{array}{c}\text { Pre-treatment } \\
\text { of MKN45 }\end{array}$ & No pre-treatment \\
\hline 0 & $\mathrm{NT}$ & $\mathrm{NT}$ & $186.6(92.0) \dagger$ \\
8 & $42.2(25.4) \ddagger$ & $185.9(51.3)$ & $182.3(86.8)$ \\
40 & $27.8(16.5)_{\ddagger}^{\dagger}$ & $175.9(81.3)$ & $170.6(83.8)$ \\
200 & $24.6(15.1) \ddagger$ & $161.4(73.1)$ & $115.6(54.9) \S$ \\
\hline
\end{tabular}

NT, not tested.

* Mean fluorescence intensity of negative control of MKN45 cells was 2.7 (SD 0.9).

$\dagger$ Mean \pm SD of the mean.

$\$$ Statistically significant $(p<0.0001)$ in comparison to control without MAbH20.

$\S$ Statistically significant $(\mathrm{p}<0.001)$ in comparison to control without $\mathrm{MAbH} 20$

sensitive to $H$. pylori adhesion. The results indicate that unknown host factors are associated with the adhesion of $H$. pylori to gastric epithelial cells.

The adhesion of $H$. pylori to the primary human gastric epithelial cells was inhibited by MAbH20 directed against $H$. pylori HSP60. These findings indicate that $H$. pylori HSP60 might be associated with adhesion of $H$. pylori not only to MKN45 but also to human primary gastric epithelial cells.

However, the inhibition of adhesion of $H$. pylori to MKN45 and the prepared human gastric epithelial cells by MAbH20 was not complete. The reason for these phenomena might be explained by the fact that the association between the adhesin(s) of $H$. pylori

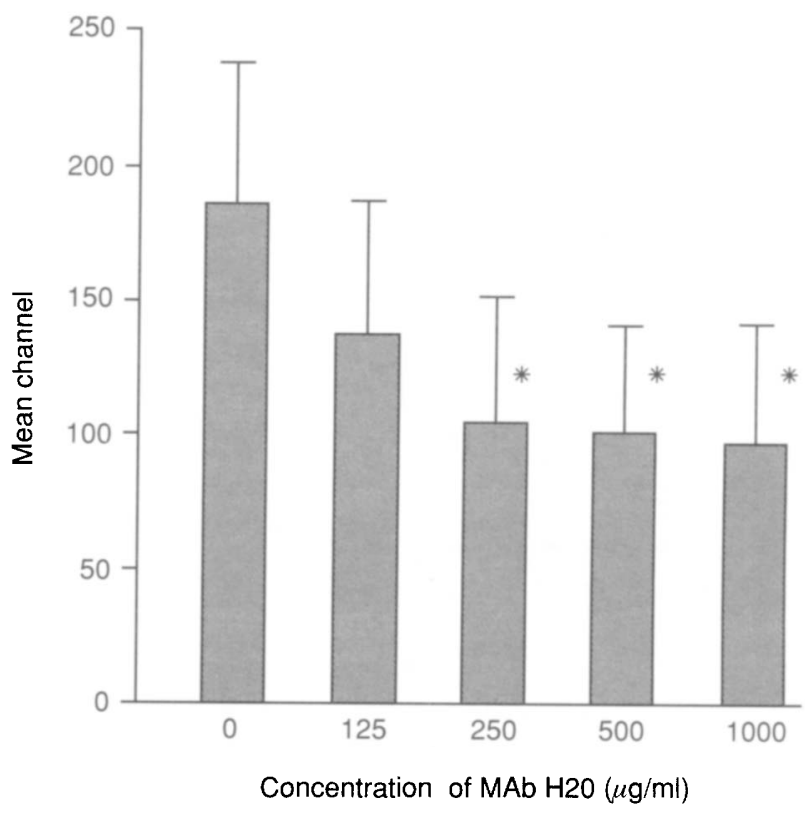

Fig. 4. The inhibitory effect of MAbH20 on the adhesion of $H$. pylori to primary human gastric epithelial cells. Adhesion was evaluated by flow cytometric analysis when $H$. pylori was pre-treated with $\mathrm{MAbH} 20(0-$ $1000 \mu \mathrm{g} / \mathrm{ml}$ ). Mean fluorescence intensity of primary human gastric epithelial cells only as negative control was 3.1 (SD 1.0). * Statistically significant $(p<0.001)$ in comparison to $\mathrm{MAbH} 20$-untreated control.

and host receptors is multifactorial [13-17] (Fig. 5). In addition, it is speculated that the intensity of the expression of the receptor for $H$. pylori HSP60 on the surface is different in prepared human gastric epithelial cells and in established human gastric

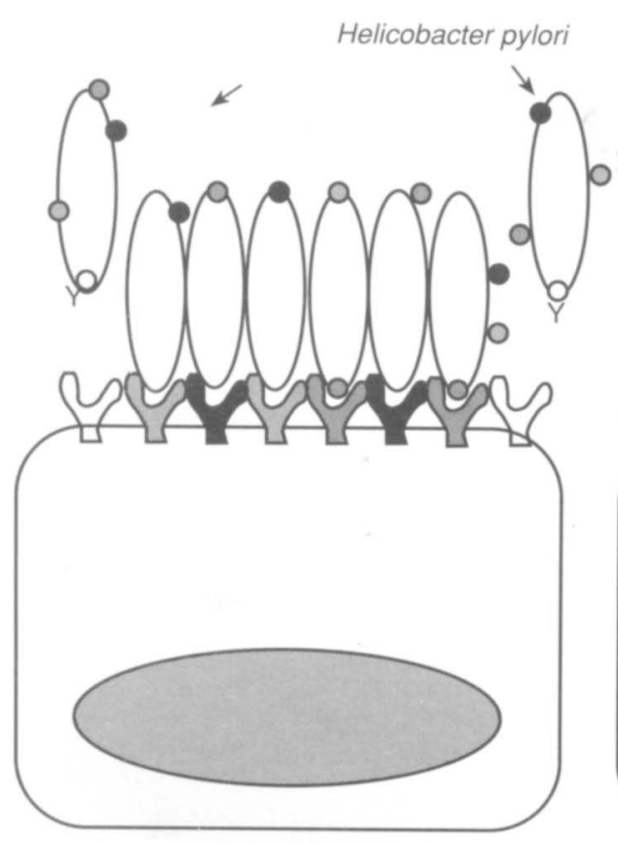

Human gastric epithelial cell

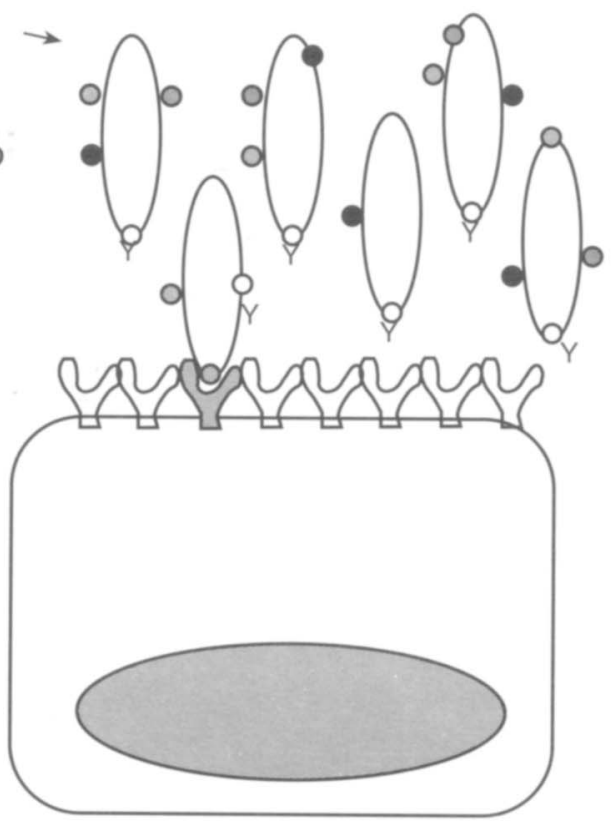

Human gastric cancer cell MKN45

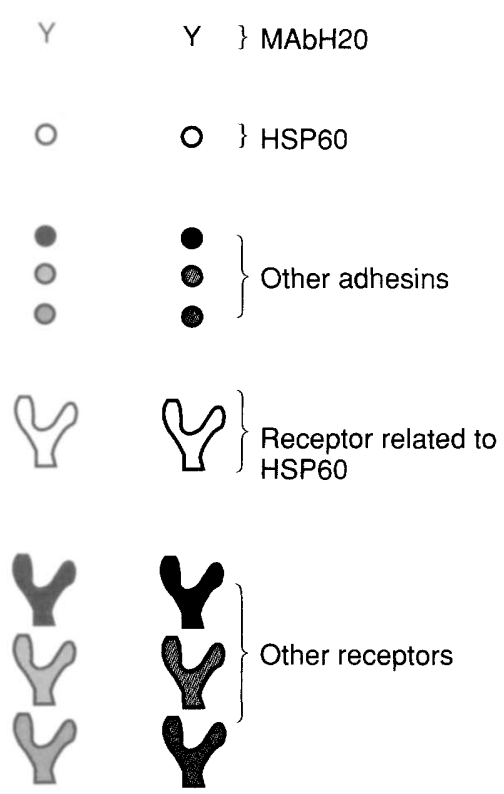

Fig. 5. Hypothetical scheme to explain the adhesion of $H$. pylori to human gastric epithelial cells and human gastric cancer MKN45 cells. 
cancer MKN45 cells (Fig. 5). Further studies are in progress to determine whether $H$. pylori HSP60 is directly associated with the adhesion of $H$. pylori to human gastric epithelial cells.

This study was supported in part by a grant for scientific research from the Ministry of Education, Science, Sport and Culture of Japan.

\section{References}

1. Blaser MJ. Hypotheses on the pathogenesis and natural history of Helicobacter pylori induced inflammation. Gastroenterology 1992; 102: 720-727.

2. Parsonnet J, Friedman GD, Vandersteen DP et al. Helicobacter pylori infection and the risk of gastric carcinoma. $N$ Engl $J$ Med 1991; 325: 1127-1131.

3. Parsonnet J, Hansen S, Rodriguez L et al. Helicobacter pylori infection and gastric lymphoma. $N$ Engl $J$ Med 1994; 330: $1267-1271$.

4. Eaton KA, Morgan DR, Krakowka S. Campylobacter pylori virulence factors in gnotobiotic piglets. Infect Immun 1989; 57 : $1119-1125$.

5. O'Toole PW, Kostrzynska M, Trust TJ. Non-motile mutants of Helicobacter pylori and Helicobacter mustelae defective in flagellar hook production. Mol Microbiol 1994; 14: 691-703.

6. Evans DG, Evans DJ, Moulds JJ, Graham DY. N-acetylneuraminyllactose-binding fibrillar hemagglutinin of Campylobacter pylori: a putative colonization factor antigen. Infect Immun 1988; 56: 2896-2906.

7. Eaton KA, Krakowka S. Effect of gastric $\mathrm{pH}$ on ureasedependent colonization of gnotobiotic piglets by Helicobacter pylori. Infect Immun 1994; 62: 3604-3607.

8. Segal ED, Shon J, Tompkins LS. Characterization of Helicobacter pylori urease mutants. Infect Immun 1992; 60: 1883-1889.

9. Leunk RD, Johnson PT, David BC, Kraft WG, Morgan DR. Cytotoxic activity in broth-culture filtrates of Campylobacter pylori. J Med Microbiol 1988; 26: 93-99.

10. Kamiya S, Kai M, Ozawa A et al. Characteristics of vacuolating toxin produced by Helicobacter pylori. Eur $J$ Gastroenterol Hepatol 1994; 6 Suppl 1: S23-S27.

11. Cave DR, Vargas M. Effect of a Campylobacter pylori protein on acid secretion by parietal cells. Lancet 1989; 2: 187-189.

12. Peterson WL. Helicobacter pylori and peptic ulcer disease. $N$ Engl J Med 1991; 324: 1043-1048.

13. Lelwala-Guruge $\mathrm{J}$, Ljungh $\AA$, Wadström T. Haemagglutination patterns of Helicobacter pylori: frequency of sialic acidspecific and non-sialic acid-specific haemagglutinins. APMIS 1992; 100 Suppl 28: 908-913.

14. Moran AP, Kuusela P, Kosunen TU. Interaction of Helicobacter pylori with extracellular matrix proteins. J Appl Bacteriol 1993; 75: 184-189.

15. Saito T, Natomi H, Zhao $\mathrm{W}$ et al. Identification of glycolipid receptors for Helicobacter pylori by TLC-immunostaining. FEBS Lett 1991; 282: 385-387.

16. Slomiany BL, Piotrowski J, Samanta A, Vanhorn K, Murty
VLN, Slomiany A. Campylobactor pylori colonization factor shows specificity for lactosylceramide sulfate and GM3 ganglioside. Biochem Int 1989; 19: 929-936.

17. Trust TJ, Doig P, Emody L, Kienle Z, Wadstrom T, O'Toole P. High-affinity binding of the basement membrane proteins collagen type IV and laminin to the gastric pathogen Helicobacter pylori. Infect Immun 1991; 59: 4398-4404.

18. Yamaguchi $H$, Osaki $T$, Taguchi $H$, Hanawa $T$, Yamamoto $T$, Kamiya S. Flow cytometric analysis of the heat shock protein 60 expressed on the cell surface of Helicobacter pylori. J Med Microbiol 1996; 45: 270-277.

19. Huesca M, Borgia S, Hoffman P, Lingwood CA. Acidic pH changes receptor binding specificity of Helicobacter pylori: a binary adhesion model in which surface heat shock (stress) proteins mediate sulfatide recognition in gastric colonization. Infect Immun 1996; 64: 2643-2648.

20. Born W, Happ MP, Dallas A et al. Recognition of heat shock proteins and gamma-delta cell function. Immunol Today 1990; 11: $40-43$.

21. Kaufmann SHE, Schoel B, Wand-Wurttenburger A, Steinhoff U, Munk ME, Koga T. T-cells, stress proteins and pathogenesis of mycobacterial infections. Curr Top Microbiol Immunol 1990; 155: $125-141$

22. Young DB. Chaperonins and the immune response. Semin Cell Biol 1990; 1: 27-36.

23. Creighton TE. Unfolding protein folding. Nature 1991; 352: $17-18$.

24. Ellis RJ. The molecular chaperone concept. Semin Cell Biol 1990; 1: $1-10$

25. Hemmingsen SM, Woolford C, van der Vies SM et al. Homologous plant and bacterial proteins chaperone oligomeric protein assembly. Nature 1988; 333: 330-334.

26. Kamiya S, Taniguchi I, Yamamoto $\mathrm{T}$ et al. Evaluation of rapid urease test for detection of Helicobacter pylori in gastric biopsy specimens. Eur J Epidemiol 1993; 9: 450-452.

27. Yamaguchi $\mathrm{H}$, Yamamoto $\mathrm{T}$, Taguchi $\mathrm{T}$, Ogata $\mathrm{S}$. Yersinia enterocolitica immunodominant $60 \mathrm{kDa}$ antigen, common to a broad range of bacteria, is a heat-shock protein. $J$ Gen Microbiol 1990; 136: 1091-1097.

28. Yamaguchi H, Taguchi H, Katura T, Kumada J, Uekusa T, Ogata S. Purification of cross-reacting protein antigen shared by Yersinia enterocolitica and other gram-negative bacteria with monoclonal antibody. Microbiol Immunol 1989; 33: 683688.

29. Yamamoto-Osaki $T$, Yamaguchi $H$, Taguchi $H$, Ogata $S$, Kamiya S. Adherence of Helicobacter pylori to cultured human gastric carcinoma cells. Eur $J$ Gastroenterol Hepatol 1995; 7 Suppl 1: S89-S92.

30. Taguchi H, Osaki T, Yamaguchi H, Kamiya S. Flow cytometric analysis using lipophilic dye PKH-2 for adhesion of Vibrio cholerae to intestine 407 cells. Microbiol Immunol 1995; 39: 891-894.

31. Macchia G, Massone A, Burroni D, Covacci A, Censin S, Rappuoli R. The Hsp60 protein of Helicobacter pylori: structure and immune response in patients with gastroduodenal diseases. Mol Microbiol 1993; 9: 645-652.

32. Phadnis SH, Parlow MH, Levy M et al. Surface localization of Helicobacter pylori urease and a heat shock protein homolog requires bacterial autolysis. Infect Immun 1996; 64: 905-912. 